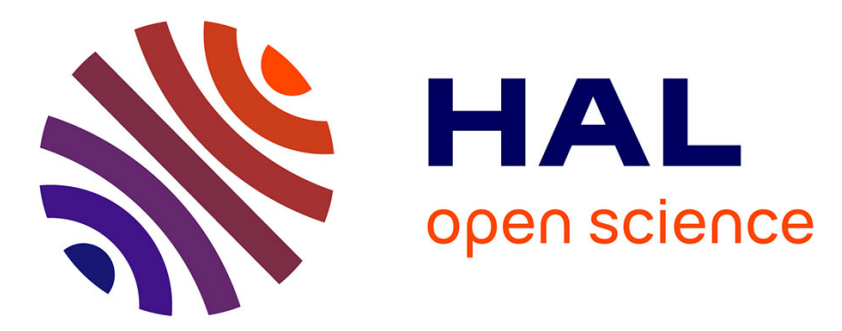

\title{
Total organic and inorganic carbon exchange through the Strait of Gibraltar in September 1997
}

Evgeny Dafner, Melchor Gonzalez-Davila, J. Magdalena Santana-Casiano, Richard Sempere

\section{- To cite this version:}

Evgeny Dafner, Melchor Gonzalez-Davila, J. Magdalena Santana-Casiano, Richard Sempere. Total organic and inorganic carbon exchange through the Strait of Gibraltar in September 1997. Deep Sea Research (1953), 2001, 8 (5), pp.1217 - 1236. 10.1016/S0967-0637(00)00064-9 . hal-02063115

\section{HAL Id: hal-02063115 \\ https://hal-amu.archives-ouvertes.fr/hal-02063115}

Submitted on 10 Mar 2019

HAL is a multi-disciplinary open access archive for the deposit and dissemination of scientific research documents, whether they are published or not. The documents may come from teaching and research institutions in France or abroad, or from public or private research centers.
L'archive ouverte pluridisciplinaire HAL, est destinée au dépôt et à la diffusion de documents scientifiques de niveau recherche, publiés ou non, émanant des établissements d'enseignement et de recherche français ou étrangers, des laboratoires publics ou privés. 


\title{
Total organic and inorganic carbon exchange through the Strait of Gibraltar in September 1997
}

\author{
Evgeny Dafner ${ }^{a}, *$, Melchor González-Dávila ${ }^{\mathrm{b}}$, \\ J. Magdalena Santana-Casiano ${ }^{\mathrm{b}}$, Richard Sempéré \\ ${ }^{a}$ Microbiologie Marine (CNRS/ INSU, EP2032), Université de la Mediterranée - Campus de Luminy, Case 907, Marseille \\ Cedex 9, France \\ ${ }^{\mathrm{b}}$ Departamento de Química, Universidad de Las Palmas de Gran Canaria, 35017 Las Palmas GC, Spain
}

Received 27 September 1999; received in revised form 9 March 2000; accepted 7 June 2000

\begin{abstract}
The total organic carbon (TOC) and total inorganic carbon $\left(C_{\mathrm{T}}\right)$ exchange between the Atlantic Ocean and the Mediterranean Sea was studied in the Strait of Gibraltar in September 1997. Samples were taken at eight stations from western and eastern entrances of the Strait and at the middle of the Strait (Tarifa Narrows). TOC was analyzed by a high-temperature catalytic oxidation method, and $C_{\mathrm{T}}$ was calculated from alkalinity- $\mathrm{pH}_{\mathrm{T}}$ pairs and appropriate thermodynamic relationships. The results are used in a two-layer model of water mass exchange through the Strait, which includes the Atlantic inflow, the Mediterranean outflow and the interface layer in between. Our observations show a decrease of TOC and an increase of $C_{\mathrm{T}}$ concentrations from the surface to the bottom: $71-132 \mu \mathrm{M} \mathrm{C}$ and $2068-2150 \mu \mathrm{mol} \mathrm{kg}^{-1}$ in the Surface Atlantic Water, $74-95 \mu \mathrm{M} \mathrm{C}$ and $2119-2148 \mu \mathrm{mol} \mathrm{kg}^{-1}$ in the North Atlantic Central Water, 63-116 $\mu \mathrm{M}$ $\mathrm{C}$ and $2123-2312 \mu \mathrm{molkg} \mathrm{kg}^{-1}$ in the interface layer, and $61-78 \mu \mathrm{M} \mathrm{C}$ and $2307-2325 \mu \mathrm{mol} \mathrm{kg}^{-1}$ in the Mediterranean waters. However, within the Mediterranean outflow, we found that the concentrations of carbon were higher at the western side of the Strait (75-78 $\left.\mu \mathrm{M} \mathrm{C}, 2068-2318 \mu \mathrm{mol} \mathrm{kg}^{-1}\right)$ than at the eastern side (61-69 $\left.\mu \mathrm{M} \mathrm{C}, 2082-2324 \mu \mathrm{mol} \mathrm{kg}^{-1}\right)$. This difference is due to the mixing between the Atlantic inflow and the Mediterranean outflow on the west of the Strait, which results in a flux of organic carbon from the inflow to the outflow and an opposite flux of inorganic carbon. We estimate that the TOC input from the Atlantic Ocean to the Mediterranean Sea through the Strait of Gibraltar varies from $(0.97 \pm 0.8) 10^{4}$ to $(1.81 \pm 0.90) 10^{4} \mathrm{~mol} \mathrm{C} \mathrm{s}^{-1}\left(0.3 \times 10^{12}\right.$ to $\left.0.56 \times 10^{12} \mathrm{~mol} \mathrm{C} \mathrm{yr}^{-1}\right)$, while outflow of inorganic carbon ranges from $(12.5 \pm 0.4) 10^{4}$ to $(15.6 \pm 0.4) 10^{4} \mathrm{~mol} \mathrm{C} \mathrm{s}^{-1}\left(3.99-4.90 \times 10^{12} \mathrm{~mol} \mathrm{C} \mathrm{yr}^{-1}\right)$. The high variability of carbon exchange within the Strait is due to the variability of vertical mixing between inflow and outflow along the Strait. The prevalence of organic carbon inflow and inorganic carbon outflow shows the
\end{abstract}

\footnotetext{
* Correspondence address: Center for Marine Science, University of North Carolina at Wilmington, One Marvin K. Moss Lane, Wilmington NC 28409, USA. Tel.: +1-910-962-2361; Fax: + 1-910-962-2410.

E-mail address: dafnere@uncwil.edu (E. Dafner).
} 
Mediterranean Sea to be a basin of active remineralization of organic material. (C) 2001 Elsevier Science Ltd. All rights reserved.

Keywords: Water exchange; Chemical oceanography; Carbon

\section{Introduction}

The average annual increase of $\mathrm{CO}_{2}$ in the atmosphere has been estimated to be about $1.4 \mathrm{ppm} \mathrm{yr}^{-1}$, with a year-to-year fluctuation about the mean of about $\pm 0.6 \mathrm{ppm} \mathrm{yr}^{-1}$ (Gammon et al., 1985; Conway et al., 1994). It has long been recognized that the oceans are the most intense sink of carbon dioxide in the global carbon cycle, absorbing about half of the carbon of anthropogenic origin released to the atmosphere (Siegenthaler and Sarmiento, 1993). The carbon dioxide sink in the ocean is dominated by the North Atlantic, despite its small area in comparison with the North Pacific (Watson et al., 1995). To improve the determination of regional or global carbon fluxes (and uncertainties), it is clear that more carbon observations are needed.

Estimates of the meridional total carbon dioxide flux have been presented for the whole North Atlantic (Martel and Wunsch, 1993) and for different parts of this ocean: the subtropical North Atlantic (Brewer et al., 1989), the tropical Atlantic (Broecker and Peng, 1992; Keeling and Peng, 1995), and the temperate North Atlantic Ocean (Tans et al., 1990). Meridional fluxes of dissolved organic matter in the North Atlantic have been calculated by Walsh et al. (1992). Recently total inorganic carbon $\left(C_{\mathrm{T}}\right)$ and dissolved organic carbon (DOC) transports have been evaluated by Stoll et al. $(1996 \mathrm{a}, \mathrm{b})$ for the northern North Atlantic Ocean. These authors have pointed out that the meridional transport of DOC cannot be ignored in the total carbon flux.

One step toward better interpretation of the role of the North Atlantic in the global carbon cycle is to estimate the organic and inorganic carbon exchanges between different marine basins. The Strait of Gibraltar is of special interest in this regard, because it is a single connection between the Atlantic and the Mediterranean Sea, and a comparatively well-studied region from a physical point of view. Despite this, there exists only one indirect estimate of organic and inorganic carbon exchange through this Strait (Copin-Montégut, 1993).

In response to increased interest in global carbon change and greenhouse warming, measurements of the marine carbon system (i.e., total organic carbon, titration alkalinity, $\mathrm{pH}$ ) were completed in the CANIGO project (Canary Islands Azores Gibraltar Observations, MAST III Programme). This program included a synoptic survey of spatial variability within the Strait with an emphasis on seasonal monitoring, primarily designed to examine temporal variability and the mechanisms controlling the carbon exchange between the Atlantic and the Mediterranean basins. In this paper, we describe the results of total organic and inorganic carbon exchange through the Strait of Gibraltar measured in September 1997.

\section{Study area}

The Strait of Gibraltar is a narrow and shallow connection between the Atlantic Ocean and the Mediterranean Sea (Fig. 1). It is in an east-west orientation about $60 \mathrm{~km}$ long with a minimum 




Fig. 1. Bathymetry in the Strait of Gibraltar and station grid during CANIGO 2 cruise of the RV Thalassa (2-9 September 1997). To the east of the Strait lies the Alboran Sea, the western-most basin of the Mediterranean Sea. To the west of the Strait lies the Gulf of Cadiz, an embayment in the northeast Atlantic Ocean. After La Violette and Lacombe (1988), the section made up of stations 1-3 is called the Spartel Sill section, between stations 4 and 5 the Tarifa Narrows section, and between Gibraltar and Ceuta the Gates of Hercules section.

width of about $12 \mathrm{~km}$ at the Tarifa Narrows and an average depth of about $600 \mathrm{~m}$. Thirteen kilometers west of Tarifa Narrows lies the main bathymetric sill of the Strait, the Camarinal sill, with a maximum depth of about $285 \mathrm{~m}$ and an area of about $7.86 \mathrm{~km}^{2}$ (Guimerans et al., 1988). Another sill (the Spartel sill) is situated $21 \mathrm{~km}$ west of the main sill and has a maximum depth of more than $350 \mathrm{~m}$ (La Violette and Lacombe, 1988). Between these two sills, is located the Tangier Basin, with a maximum depth of about $640 \mathrm{~m}$.

\section{Materials and methods}

\subsection{Sampling}

The seawater samples were taken at eight stations within the Strait of Gibraltar from the RV Thalassa with a CTD rosette system equipped with 101 Niskin bottles between 2 and 9 September 1997 (Fig. 1). The bottles were fired at the depths of maximum or minimum distribution of temperature, salinity, oxygen and fluorescence, within and between different water masses and at the interface layer between the Atlantic inflow and Mediterranean outflow. Samples were taken to within a few meters of the bottom. The positions of the stations are listed in Table 1. 
Table 1

Location and depth of the stations with date and time of sampling during the cruise of the RV Thalassa, 2-9 September 1997. Time of sampling corresponds to Greenwich Meridian Time and coincides with the beginning of the CTD cast

\begin{tabular}{llllc}
\hline St. no. & Stations locations & Depth $(\mathrm{m})$ & Sampling date & Time of sampling \\
\hline 1 & $5^{\circ} 54^{\prime} \mathrm{W}, 36^{\circ} 02^{\prime} \mathrm{N}$ & 160 & 2.09 .1997 & $13 \mathrm{~h} 20 \mathrm{~min}$ \\
2 & $5^{\circ} 55^{\prime} \mathrm{W}, 35^{\circ} 58^{\prime} \mathrm{N}$ & 278 & 3.09 .1997 & $9 \mathrm{~h} 00 \mathrm{~min}$ \\
3 & $5^{\circ} 55^{\prime} \mathrm{W}, 35^{\circ} 53^{\prime} \mathrm{N}$ & 417 & 4.09 .1997 & $9 \mathrm{~h} 06 \mathrm{~min}$ \\
4 & $5^{\circ} 36^{\prime} \mathrm{W}, 35^{\circ} 58^{\prime} \mathrm{N}$ & 527 & 5.09 .1997 & $9 \mathrm{~h} 10 \mathrm{~min}$ \\
5 & $5^{\circ} 36^{\prime} \mathrm{W}, 35^{\circ} 55^{\prime} \mathrm{N}$ & 550 & 6.09 .1997 & $9 \mathrm{~h} 11 \mathrm{~min}$ \\
6 & $5^{\circ} 18^{\prime} \mathrm{W}, 36^{\circ} 05^{\prime} \mathrm{N}$ & 732 & 7.09 .1997 & $7 \mathrm{hin} 50 \mathrm{~min}$ \\
7 & $5^{\circ} 18^{\prime} \mathrm{W}, 36^{\circ} 02^{\prime} \mathrm{N}$ & 827 & 8.09 .1997 & $9 \mathrm{~h} 22 \mathrm{~min}$ \\
8 & $5^{\circ} 18^{\prime} \mathrm{W}, 35^{\circ} 58^{\prime} \mathrm{N}$ & 575 & 9.09 .1997 & \\
\hline
\end{tabular}

\subsection{Total organic carbon measurements}

The $15 \mathrm{ml}$ samples were collected in glass tubes, precombusted prior to the cruise $\left(450^{\circ} \mathrm{C}\right.$, at least $6 \mathrm{~h}$ ) and closed with Teflon ${ }^{\circledR}$ PFA-backed screw caps that had been rinsed with Milli-Q water and dried. Samples were not filtered and were drawn as soon as possible after the rosette sampler was on the deck of the ship (either first or immediately following the gas samples). During sampling, seawater was allowed to flow directly from the Niskin stopcock without the stopcock touching the tubes to reduce the chance of contamination. Samples were taken in duplicate, poisoned by addition of $\mathrm{HgCl}_{2}\left(10 \mathrm{mgl}^{-1}\right.$ final concentration), stored in the dark and analyzed in the Laboratory of Marine Microbiology, CNRS, Marseille.

The Shimadzu instrument used in this study was the commercially available Model TOC-5000 total carbon analyzer with quartz combustion column in the vertical position filled with $1.2 \% \mathrm{Pt}$ silica pillows (Cauwet, 1994). A sample volume of $100 \mu \mathrm{l}$ was used. Subsamples were acidified with $10 \mu \mathrm{l}$ of $85 \% \mathrm{H}_{3} \mathrm{PO}_{4}$ and sparged for $10 \mathrm{~min}$ at a flow rate of $50 \mathrm{ml} \mathrm{min}^{-1}$ with $\mathrm{CO}_{2}$-free pure air to purge inorganic carbon. Each sample, standard or blank was injected 3-4 times. The nominal analytical precision of the procedure was within $2 \%$, but some variability in results from two different vials gives rise to an actual precision that is lower (4-6\%). The catalyst bed was conditioned by injecting $100 \mu \mathrm{l}$ of acidified and sparged Milli-Q water until the lowest stable integrated area was obtained. Standardization was carried out every day with potassium hydrogen phthalate diluted in Milli-Q water (three concentrations).

The instrument response factor, measured as the slope of the standard addition to Milli-Q water $\left(r^{2}>0.999\right.$ for 11 runs), remained relatively constant and reproducible over the time of analysis. In general, calibration curves did not exhibit differences in slope (average slope: $5917 \pm 184, N=11$ ), and the bias between slopes was within approximately $3 \%$. The system blank was determined by analyzing low-carbon water (LCW) from ampoules provided by J. Sharp (University of Delaware) and was found to be about $5 \mu \mathrm{M} \mathrm{C}$ (the average DOC concentration in the Deep Pacific Water reference was $42 \pm 5 \mu \mathrm{M} \mathrm{C}$ ). The total organic carbon (TOC) concentrations in samples were calculated by averaging all replicate sample injections, subtracting the average LCW value as the total blank and dividing by the slope of the standard curve. 
Intercalibration exercises in 1995, organized by Dr. J.H. Sharp, indicated that our instrument was suitable for marine DOC studies.

\subsection{Total inorganic carbon}

Total inorganic carbon $\left(C_{\mathrm{T}}\right)$ was computed from experimental values of $\mathrm{pH}_{\mathrm{T}}$ and total alkalinity, the carbonic acid dissociation constants of Roy et al. (1993), and the boric acid dissociation constant of Dickson (1990). Several authors have examined the thermodynamic consistency of the measured components of the carbonate system (e.g., Millero et al., 1993; Clayton et al., 1995; Lee et al., 1997; McElligott et al., 1998). From these studies it appears that at present it is not possible to draw a firm conclusion regarding the best set of constants to use. Considering the accuracy of photometric $\mathrm{pH}( \pm 0.002)$ and potentiometric total alkalinity $\left( \pm 1 \mu \mathrm{mol} \mathrm{kg}^{-1}\right)$ determinations (Mintrop et al., 1999), Lee et al. (1997) estimated that the probable errors in $C_{\mathrm{T}}$ determined with the Roy et al. (1993) constants is around $4 \mu \mathrm{mol} \mathrm{kg}^{-1}$. This is slightly higher than the accuracy of the experimental value ( $\pm 2 \mu \mathrm{mol} \mathrm{kg}{ }^{-1}$, Johnson et al., 1993). Recent determinations of $\mathrm{pH}_{\mathrm{T}}, A_{\mathrm{T}}$ and $C_{\mathrm{T}}$ in the Azores area have shown internal consistency among these paramenters. $C_{\mathrm{T}}$ measured was only, on average, $0.54 \mu \mathrm{mol} \mathrm{kg}{ }^{-1}$ higher than $C_{\mathrm{T}}$ calculated, with a standard deviation of $\pm 2.6 \mu \mathrm{mol} \mathrm{kg}^{-1}$, when the Roy et al. (1993) constants were used (Mintrop and González-Dávila, unpublished observations).

The $\mathrm{pH}$ on the total scale was measured following the spectrophotometric technique of Clayton and Byrne (1993) using the $m$-cresol purple indicator (DOE, 1994). A system similar to that described by Bellerby et al. (1995) was developed in our lab. The $\mathrm{pH}$ measurements were done with a Hewlett Packard Diode Array spectrophotometer in a $25^{\circ} \mathrm{C}$-thermostated 1 -cm flow-cell by using a Peltier system. Using a stopped-flow protocol, seawater previously thermostated to $25^{\circ} \mathrm{C}$ was analyzed for blank determinations at 730, 578 and $434 \mathrm{~nm}$. The flow was restarted and the indicator injection valve switched on to inject $10 \mu \mathrm{l}$ dye through a mixing coil $(2 \mathrm{~m})$. Three photometric measurements were carried out for each injection in order to remove any dye effect on the seawater $\mathrm{pH}$ measurement.

Total alkalinity of seawater was determined by titration with $\mathrm{HCl}$ to the carbonic acid end point using two potentiometric systems (Millero et al., 1993) described previously (Mintrop et al., 1999). In brief, the titration systems consisted of a Titrino 702SM titrator (Metrohm, Herisau, Switzerland) and a Titrino 719S, both interfaced to personal computers. All measurements were made in thermostated plastic cells provided by F. Millero of the Rosenstiel School of Marine and Atmospheric Sciences (RSMAS), Miami, Florida. Both the acid, in a water-jacketed burette, and the seawater sample, in a water-jacketed cell, were maintained at $25^{\circ} \mathrm{C}$ with a constant temperature bath. The titration was performed by adding $\mathrm{HCl}$ to the seawater past the carbonic acid end point. A computer program was used to run the titration, record the volume of the acid added and the EMF readings of the electrodes. The $\mathrm{HCl}$ solution $(251,0.25 \mathrm{M})$ was made from concentrated analytical grade $\mathrm{HCl}$ (Merck ${ }^{\circledR}$, Darmstadt, Germany) in $0.45 \mathrm{M} \mathrm{NaCl}$, in order to yield an ionic strength similar to open ocean seawater. The acid was standardized by the titration of weighed amounts of $\mathrm{Na}_{2} \mathrm{CO}_{3}$ dissolved in $0.7 \mathrm{M} \mathrm{NaCl}$ solution resulting in a value of $0.2505 \pm 0.0001 \mathrm{M}$. The acid concentration was also determined by coulometry at RSMAS (F. Millero). The results of both methods agree within \pm 0.0001 . The total alkalinity of seawater was evaluated from the proton balance at the alkalinity equivalence point, $\mathrm{pH}_{\text {equiv }}=4.5$, according to the exact definition 
of total alkalinity (Dickson, 1981). A FORTRAN computer program (provided by F. Millero) was used to calculate the carbonate parameters (Millero et al., 1993). The precision of the fit ( $s$ value) is better than $0.4 \mu \mathrm{mol} \mathrm{kg}{ }^{-1}$ for the samples analyzed. The performance of the titration systems was monitored by titration of different batches of CRM (\#35) that have known $C_{\mathrm{T}}$ and $A_{\mathrm{T}}$. The agreement of our alkalinity values with the CRM data was within $\pm 1.5 \mu \mathrm{mol} \mathrm{kg}^{-1}$.

\section{Results and discussion}

\subsection{Hydrography}

Over the past decade it has been shown that 'the present dynamical understanding of the exchange through the Strait of Gibraltar is that it is hydraulically controlled so that the physical dimensions of the Strait combined with the overall evaporation over the Mediterranean basin determine how much flow can get through the Strait and how much saltier the Mediterranean is than the Atlantic' (Bryden and Kinder, 1991; Kinder and Bryden, 1992). A classical model of water mass exchange through the Strait of Gibraltar suggests that two water layers interact in the Strait: the Atlantic inflow, which spreads to the Mediterranean Sea, and the Mediterranean outflow, which outflows from the Mediterranean Sea. Inflow slightly exceeds outflow to balance the net loss from the excess of evaporation over the Mediterranean Sea. The interaction of these water bodies within the Strait produces an extremely strong halocline, which allows identification of a third transition or interface layer between them (Wesson and Gregg, 1994; Bray et al., 1995). Table 2 gives some characteristics of the water bodies found within the Strait in September 1997.

The Atlantic inflow forms in the Gulf of Cádiz and is a mixture of Surface Atlantic Water (SAW; salinity of about 36.46), North Atlantic Central Water (NACW, salinity less than 36.00), and Spanish Coastal Water (SCW, salinity of about 36.10 (Van Geen et al., 1988, 1991)). The thickness of the Atlantic inflow is highly variable, and in September 1997 it decreased from about $120 \mathrm{~m}$ above the Southern Spartel sill to 40-50 m along the Gates of Hercules section (Table 2).

The interface layer is defined by a sharp halocline with a change in salinity of about 1.50 , occurring at a depth between 40 and $230 \mathrm{~m}$ (Table 2). Lacombe and Richez (1982) used the salinity values 37.00-37.50, and Bryden et al. (1989) the values 36.50-38.00 to characterize the interface layer between the two flows. Following Bryden et al. (1994) and Bray et al. (1995), we have divided the interface layer at its mid-depth and incorporated the upper part of the interface into the upper layer and the lower part into the lower layer. Salinity values for the mid-depth are 37.00 for the Spartel sill section, 37.32 for the Tarifa Narrows and 37.50 for the Gates of Hercules section. The interface layer was found to be deeper, thicker, fresher and colder on the west of the Strait. As seen from Table 2, along the Spartel sill section, there is evident slope of the interface layer from the north $(46 \mathrm{~m})$ to the south $(125 \mathrm{~m})$. The shallowest position of this layer was found along the Gates of Hercules section (40-50 m), where it continued to get saltier and warmer.

The high-density Mediterranean outflow is marked by high salinity and temperature. It forms by a mixing of Levantine Intermediate Water (LIW) and Western Mediterranean Deep Water (WMDW). The LIW originates in the eastern Mediterranean and is characterized by intermediate maxima in temperature (about $13.00^{\circ} \mathrm{C}$ ) and salinity (about 38.50) (Kinder and Bryden, 1990). The residual LIW is found preferentially in the northwestern part of the Alboran Sea in a depth band of 


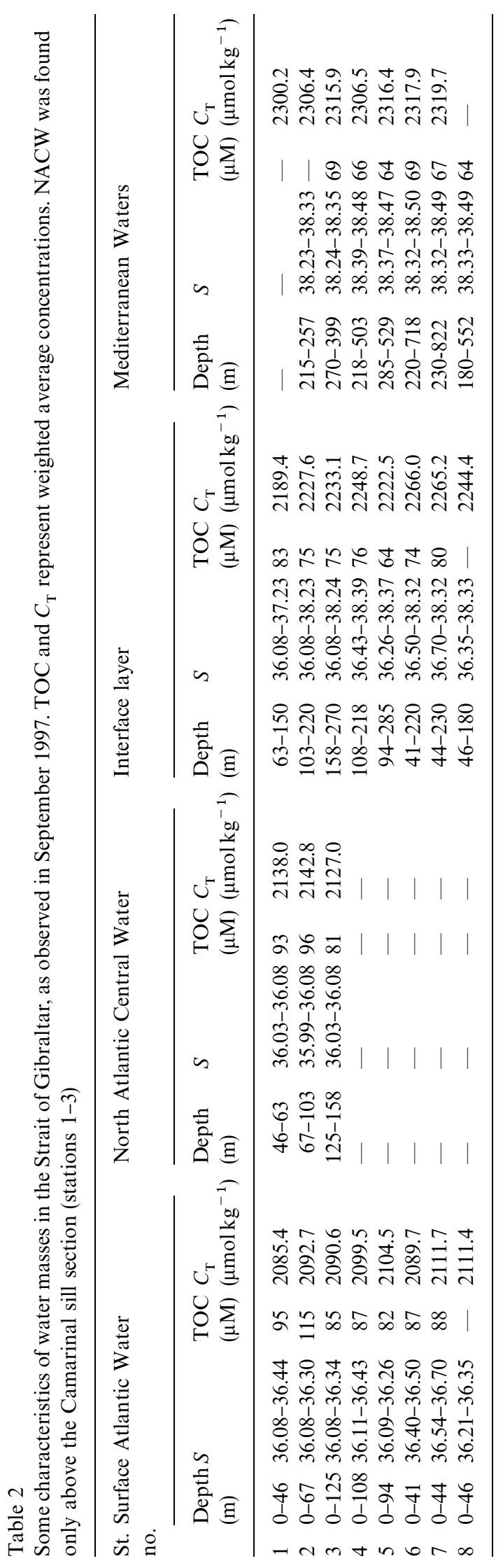


200-600 $\mathrm{m}$ and is essentially absent near the African coast. The maximum salinity values (ca. 38.50) were observed at the Tarifa Narrows and along the Gates of Hercules section (Table 2). WMDW is formed by the winter convection south of France (Medoc Group, 1970; Stommel, 1972) and is characterized by decreasing salinity and temperature $\left(38.42-38.44\right.$ and $\left.<12.90^{\circ} \mathrm{C}\right)$. The salinity distribution in Fig. 2 demonstrates that at Tarifa Narrows and along the Gates of Hercules, values of salinity in the near-bottom layer were about 38.45, always higher than those defining WMDW. A similar situation, which indicates a small contribution of WMDW to the outflow, has been described previously by a number of other investigators (Roether and Weiss, 1975; Measures and Edmond, 1988; Minas et al., 1991).

The water exchange through the Strait is under the influence of periodic forces, such as tides (La Violette and Lacombe, 1988), and aperiodic forces, such as atmospheric pressure (Stanton, 1983), wind stress over the western Mediterranean Sea and the Gulf of Cádiz (Gründlich, 1981), formation of the WMDW during winter convection, and features of the Alboran Gyre circulation (Bryden and Stommel, 1982). As a result, the water flow in the Strait is not in the form of continuous currents but rather in tidally induced pulses, which vary in the amount of water they contain according to the daily and monthly variation in the above-mentioned factors. Additionally, tide pulses are strongly affected by the bathymetric constriction (the small cross section and the presence of the sills). These short-period pulses are able to trigger very short internal waves and current fronts in the upper layer, which propagate eastward into the Alboran Sea during the flood tide (Boyce, 1975; LaViolette and Lacombe, 1988; Alpers et al., 1996).

\subsection{TOC and $C_{\mathrm{T}}$ vertical distributions}

Because of the great variability of the dynamic environment, it is difficult to present any maps or vertical sections from direct observations from the Strait of Gibraltar. Moreover, our presentation here is limited to discussion of vertical profiles of TOC and $C_{\mathrm{T}}$ distributions (Fig. 2). For a general impression of spatial variability of both organic and inorganic carbon, the weighted concentrations of TOC and $C_{\mathrm{T}}$ for each water layer were also calculated (Table 2).

The main feature of the TOC vertical distribution in Fig. 2 is the presence of several maxima, located in the SAW (almost at all stations) and in the interface layer (St. 2, 4, 6, 7). The $C_{\mathrm{T}}$ vertical distribution shows an increasing concentration from the surface to the base of the interface layer and homogeneous values within the Mediterranean waters. An additional feature of the $C_{\mathrm{T}}$ vertical distribution is a subsurface maximum located in the NACW (St. 2, 3). Fig. 2 shows that the TOC concentrations in the SAW ranged from $71 \mu \mathrm{M} \mathrm{C}$ (St. 7, 30 m) to $132 \mu \mathrm{M}$ C (St. 2, 60 m) while $C_{\mathrm{T}}$ ranged from $2068 \mu \mathrm{mol} \mathrm{kg}{ }^{-1}$ (St. $1,17 \mathrm{~m}$ ) to $2150 \mu \mathrm{mol} \mathrm{kg}{ }^{-1}$ (St. 4, $108 \mathrm{~m}$ ). Fig. 2 also shows that the upper maximum of TOC was related to the maximum of chlorophyll $a$. Table 2 shows the decrease of TOC and the increase of $C_{\mathrm{T}}$ integrated concentrations within SAW from the Atlantic Ocean side to the Mediterranean.

Signals of the NACW, with salinity values lower than 36.08, were found only above the Spartel sill (St. 1-3) with TOC and $C_{\mathrm{T}}$ concentrations of $74-95 \mu \mathrm{M} \mathrm{C}$ and $2119-2148 \mu \mathrm{mol} \mathrm{kg}^{-1}$. In the interface layer TOC concentrations ranged from $63 \mu \mathrm{M} \mathrm{C}$ (St. 5, $237 \mathrm{~m}$ ) to $116 \mu \mathrm{M} \mathrm{C}$ (St. 7, $51 \mathrm{~m}$ ). For this layer, $C_{\mathrm{T}}$ concentrations varied from $2123 \mu \mathrm{mol} \mathrm{kg}{ }^{-1}$ (St. $5,100 \mathrm{~m}$ ) to $2312 \mu \mathrm{mol} \mathrm{kg}^{-1}$ (St. 4, $212 \mathrm{~m})$. The lowest TOC and the highest $C_{\mathrm{T}}$ values were observed in the Mediterranean waters (Table 2): $61 \mu \mathrm{M}$ C (St. 6, $718 \mathrm{~m}$; St. 7, $61 \mathrm{~m}$; St. 8, $201 \mathrm{~m}$ ) to $78 \mu \mathrm{M} \mathrm{C}$ (St. 6, $100 \mathrm{~m}$ ) and 

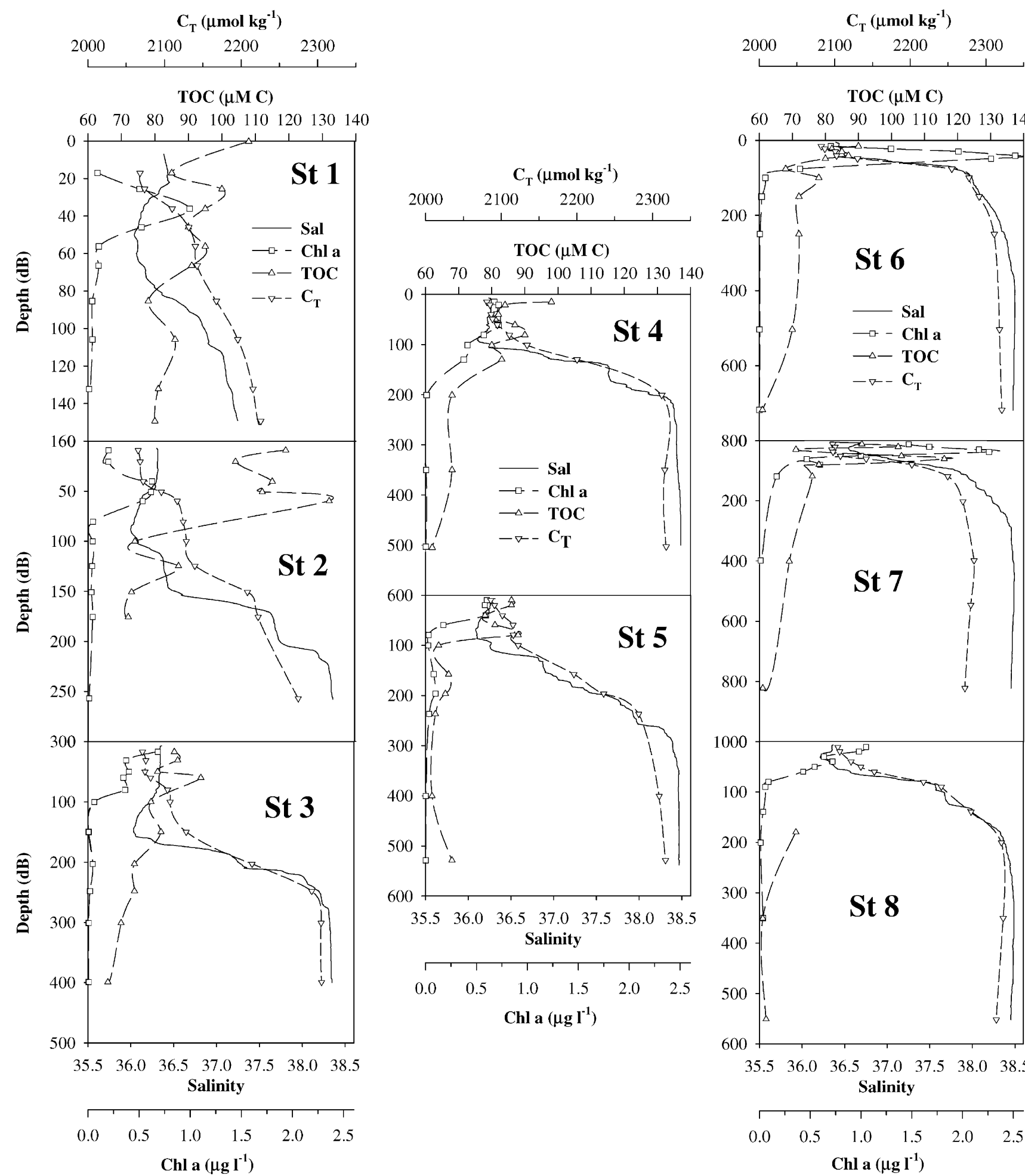

TOC $(\mu \mathrm{M} \mathrm{C})$

$\begin{array}{lllllllll}60 & 70 & 80 & 90 & 100 & 110 & 120 & 130 & 140\end{array}$
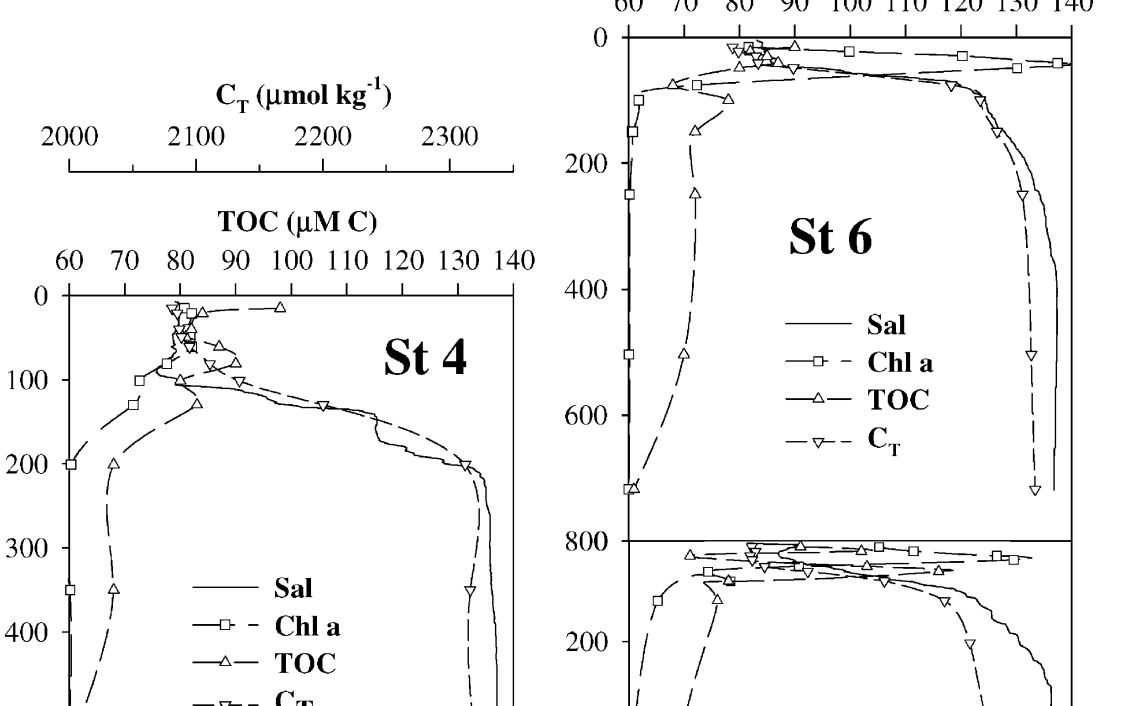
$2307 \mu \mathrm{mol} \mathrm{kg}^{-1}$ (St. 3, $301 \mathrm{~m}$ ) to $2325 \mu \mathrm{mol} \mathrm{kg}^{-1}$ (St. 7, $398 \mathrm{~m}$ ). However, in these waters, the Atlantic side in general shows higher TOC $(75-78 \mu \mathrm{M} \mathrm{C})$ and lower $C_{\mathrm{T}}\left(2068-2318 \mu \mathrm{mol} \mathrm{kg}^{-1}\right)$ concentration than the Mediterranean side $\left(65-69 \mu \mathrm{M} \mathrm{C}\right.$ and $\left.2082-2324 \mu \mathrm{mol} \mathrm{kg}^{-1}\right)$. By contrast, the integrated values show (Table 2) that the difference between TOC concentrations in the Mediterranean waters above the Spartel sill and between Gibraltar and Ceuta is at the limit of TOC determination $( \pm 5 \mu \mathrm{M} \mathrm{C})$.

TOC values measured in September 1997 are similar to those reported by various investigators in the different seas of the Mediterranean basin (Cauwet et al., 1990; Cauwet, 1991; Avril and Copin-Montégut, 1992; Copin-Montégut and Avril, 1993a, b; Cauwet et al., 1997; Yoro et al., 1997) and in the Atlantic Ocean (Carlson et al., 1994; Thomas et al., 1995; Doval et al., 1997). Similar TOC concentrations were also found in the Strait of Gibraltar in June 1997 (Dafner et al., 1999). By contrast, Gasol et al. (1998) and Doval et al. (1999) presented DOC concentrations in deep waters of the Catalan-Balearic Sea as low as $44-52 \mu$ M C. In April 1998, lower TOC concentrations $(38-52 \mu \mathrm{M}$ C) were also measured in the LIW in the western Alboran Sea (Dafner et al., 2000b). Comparison of TOC values measured near the Gates of Hercules section in June and September 1997 with observations from April 1998 suggests a seasonal cycle of organic carbon within the LIW, implying significant bacterial turnover of the organic material in this water mass (Packard et al., 1988).

In the Mediterranean Sea, no directly measured $C_{\mathrm{T}}$ values were found in the literature; all of them are based on $\mathrm{pH}$-alkalinity data. The values reported by Pérez et al. (1986), Copin-Montégut (1993) and Frankingnoulle et al. (1990) for LIW in the Mediterranean Sea (2320-2330 $\mu \mathrm{mol} \mathrm{kg}^{-1}$ ) are similar to those reported here. Directly measured $C_{\mathrm{T}}$ values for the North-East Atlantic Central Water ranged from 2128 to $2135 \mu \mathrm{mol} \mathrm{kg}{ }^{-1}$ (Mintrop and González-Dávila, 1999, unpublished data; Rios et al., 1995), consistent with the values reported here.

\subsection{Relationships of TOC and $C_{\mathrm{T}}$ to salinity}

The description of vertical distribution of TOC and $C_{\mathrm{T}}$ presented previously does not take explicit account of tidal variability in the exchange through the Strait. Most of the outflow occurs in bursts during the semidiurnal tidal cycle: when the outflowing tide is strongest, the interface is relatively shallow and so there is a thick layer of Mediterranean water flowing swiftly over the Camarinal sill. Conversely, on the inflowing tide, the interface is relatively deep and so there is a thick layer of Atlantic water flowing swiftly into the Mediterranean. Such bursts account for more than half of the exchange across the Camarinal sill between the Atlantic and Mediterranean basins (Bryden et al., 1989; Bray et al., 1995).

To remove discrepancies caused by tidal fluctuations, relationships of TOC and $C_{\mathrm{T}}$ to salinity were developed (Fig. 3). Fig. 3 shows large departures from linearity in both TOC and $C_{\mathrm{T}}$ concentrations in the Atlantic inflow and in the upper interface layer (salinity lower than 37.00), but a linear decrease of TOC and increase of $C_{\mathrm{T}}$ values with salinity higher than 37.00. The departures are due either to biological processes or variability of salinity, which affects $C_{\mathrm{T}}$ content in seawater. Although the correlation between TOC and salinity is weak $\left(r^{2}=0.56, n=25\right)$, it is still significant. By contrast, a strong correlation is found between $C_{\mathrm{T}}$ and salinity greater than $37.00\left(r^{2}=0.97, n=96\right)$. Fig. 3 also suggests that the relationship between $C_{\mathrm{T}}$ and salinity is more significant when data from the euphotic layer are removed $\left(r^{2}=0.99, n=131\right)$; a lower $C_{\mathrm{T}}$ content 

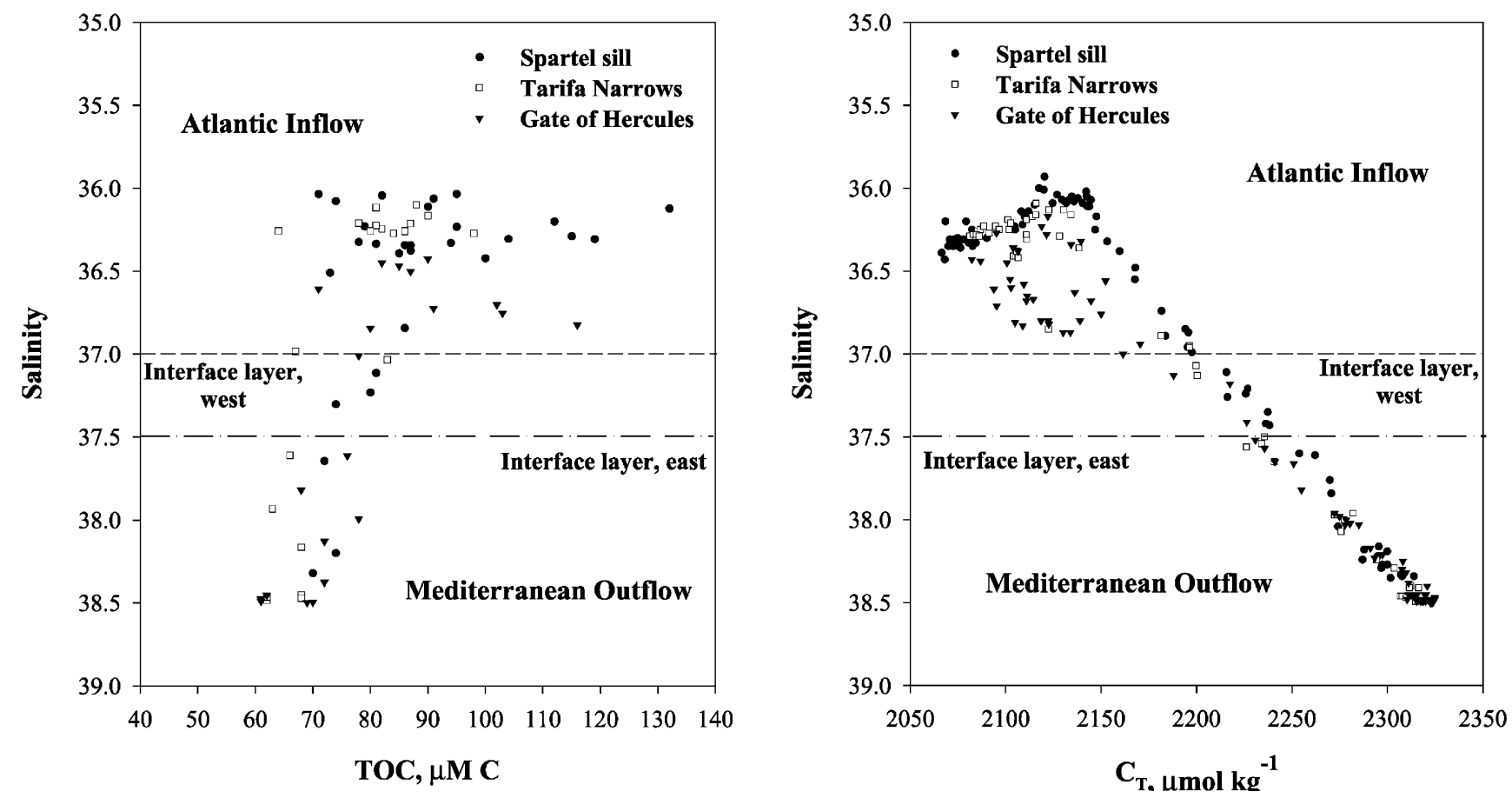

Fig. 3. Scatter plots of TOC and $C_{\mathrm{T}}$ pools vs. salinity. Strong Atlantic inflow is marked by salinity less than 36.50 , the Mediterranean outflow by salinity greater than 38.00 . Intermediate salinities depict the interface layer between the two layers, a zone where substantial periods of both inflow and outflow are typical. The 37.00 isohaline approximates an average position of the interface layer above the Spartell sill section, 37.32 at the Tarifa Narrows and 37.50 along the Gates of Hercules section.

is found there due to consumption of inorganic carbon by photosynthesis. The regression line is

$$
C_{\mathrm{T}}=2120( \pm 1.5)+79.24( \pm 0.83)(S-36.00) \text {, }
$$

which gives $C_{\mathrm{T}}$ values similar to those obtained using only the Mediterranean outflow. No $C_{\mathrm{T}}$ variation is discernible at the computed precision between waters with the same salinity but from different depths. This indicates that biological production does not have any appreciable influence on $C_{\mathrm{T}}$ in this region and that there is only a binary mixing between the Atlantic and Mediterranean waters. Brunet et al. (1984) and Copin-Montégut (1993) have presented for the Alboran Sea similar relationships between $C_{\mathrm{T}}$ and salinity. The $C_{\mathrm{T}}$ values from them are slightly lower than those reported here, but these differences could be due to the systematic differences in the $\mathrm{pH}$ measurements (photometric $\mathrm{pH}$ vs. NBS potentiometric $\mathrm{pH}$ ) and the error in the equilibrium constants (Roy et al. (1993) vs. Dickson and Millero (1987).

The specific total inorganic carbon $\left(C_{\mathrm{T}} / S\right)$ shows a linear relationship with salinity below $100 \mathrm{~m}$. A similar relationship is found for the equivalent specific total organic carbon $(\mathrm{TOC} / S)$ with salinity in the whole profile except for the chlorophyll maximum (Fig. 4). The regression lines

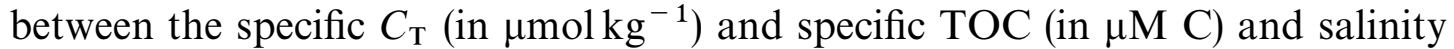

$$
\begin{aligned}
& C_{\mathrm{T}} / S=40.39(0.75)+0.516(0.020) S, \\
& \text { TOC } / S=12.46(0.92)-0.279(0.025) S,
\end{aligned}
$$




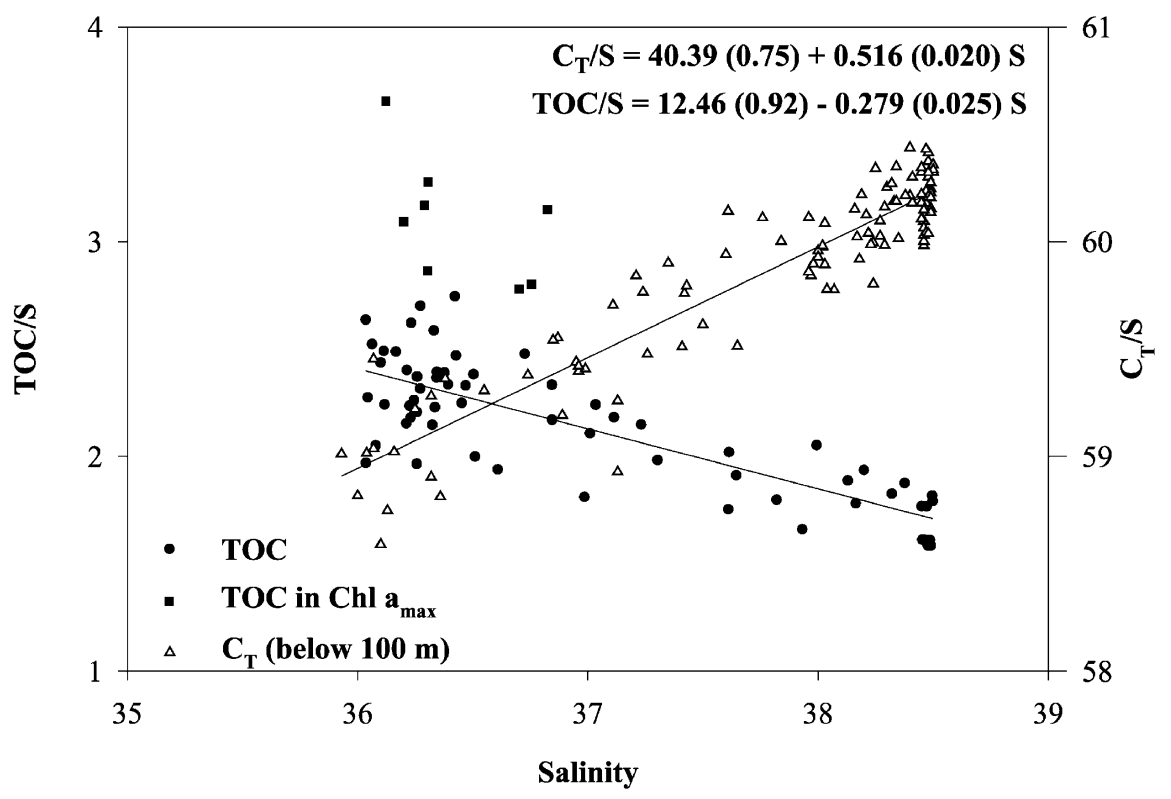

Fig. 4. Scatter plot of specific TOC and $C_{\mathrm{T}}$ vs. salinity. Linear regressions are found for $C_{\mathrm{T}}$ values below $100 \mathrm{~m}$ and TOC except for TOC values in the chlorophyll $a$ maximum.

do not pass through the origin. The specific $C_{\mathrm{T}}$ of the Mediterranean waters is higher than that of the less saline Atlantic waters. A substantial quantity of inorganic carbon is added to seawater during its residence time in the Mediterranean Sea. This enrichment may be explained by inputs from the rivers, the Black Sea, the atmosphere and the remineralization of organic carbon. The remineralization is clearly shown in the specific TOC vs. salinity plot, where the Mediterranean inflow shows a significant reduction in TOC content with respect to the Atlantic inflow.

According to Bryden et al. (1989), at salinities less than 36.50 there is a strong inflow, which we show is characterized by highest TOC and lowest $C_{\mathrm{T}}$ concentrations $(64-132 \mu \mathrm{M} \mathrm{C}$ and $\left.2068-2170 \mu \mathrm{mol} \mathrm{kg}^{-1}\right)$. For the Mediterranean water salinities greater than 38.00 , there is strong outflow, and the lowest TOC and highest $C_{\mathrm{T}}$ contents $\left(75-78 \mu \mathrm{M} \mathrm{C}\right.$ and $2274-2314 \mu \mathrm{mol} \mathrm{kg}^{-1}$ above the Spartel sill, and $65-69 \mu \mathrm{M} \mathrm{C}$ and $2278-2325 \mu \mathrm{mol} \mathrm{kg}^{-1}$ along the Gates of Hercules section) are found in the outflowing waters. For intermediate salinities, there are substantial periods of both inflow and outflow with intermediate values of TOC and $C_{\mathrm{T}}$.

\subsection{TOC and $C_{\mathrm{T}}$ balance through the Strait of Gibraltar}

In reviewing different balance estimations, Bryden and Kinder (1988) have concluded that the flows through the Strait are apparently limited, from 1 to $2 \times 10^{6} \mathrm{~m}^{3} \mathrm{~s}^{-1}$. Later estimates suggest that transports through the Strait of Gibraltar are 30\% smaller than historical estimates and, furthermore, tidal oscillations contribute nearly half of the total transport (Bryden and Kinder, 1991). Because of the great variability of the dynamic environment, it is difficult to assign, from direct observations, mean values of water transports for TOC and $C_{\mathrm{T}}$ balance calculations.

For our calculations, we use the two-layer model of water mass exchange through the Strait and present TOC and $C_{\mathrm{T}}$ budgets calculated according to the water transport estimates measured 
during the Gibraltar experiment (Bryden et al., 1994; Bray et al., 1995). Recent determinations in the framework of the CANIGO project have shown volume transport values for the eastern entrance of the Strait of 0.81 and $-0.76 \mathrm{~Sv}$ with an accuracy of $0.06 \mathrm{~Sv}$. These estimates are in good agreement with the measurements from Bryden et al. (1994) $(0.72 \pm 0.16,-0.68 \pm 0.15 \mathrm{~Sv})$. For the western entrance, the average outflow is $-0.67 \mathrm{~Sv}$ and the average inflow $0.78 \mathrm{~Sv}$ (Tsimplis and Bryden, 1999). The inflow and outflow are in reasonable balance, with a slightly higher inflow, as expected, to balance the net evaporation over the Mediterranean basin. Table 3 shows volume transport values used in this study for each section. In turn, TOC and $C_{\mathrm{T}}$ transports were estimated by dividing the interface layer according to the salinity values $(37.00,37.32$ and 37.50 from west, center and east of the Strait), and incorporating the upper part of the interface into the upper layer (Atlantic inflow) and the lower part into the lower layer (Mediterranean outflow). For budget estimations, integrated values of carbon for outflow and inflow at each station were averaged along longitudinal sections. Table 3 also shows the calculated average values of salinity, TOC and $C_{\mathrm{T}}$ for these layers, taken for the carbon fluxes estimates. Multiplying the average TOC and $C_{\mathrm{T}}$ concentrations by water transport of the upper and lower layers yields TOC and $\mathrm{C}_{\mathrm{T}}$ transports. Summarizing all carbon transports along longitudinal sections gives the carbon balance. Results of these calculations are presented in Fig. 5.

The dominant feature of carbon exchange through the Strait of Gibraltar is organic carbon inflow to the Mediterranean Sea and inorganic carbon outflow from the Mediterranean Sea. We estimate that the TOC transport from the Atlantic to the Mediterranean Sea varies from $(0.97 \pm 0.87) 10^{4}$ to $(1.81 \pm 0.90) 10^{4} \mathrm{~mol} \mathrm{C} \mathrm{s}^{-1}\left(0.30 \times 10^{12}\right.$ to $\left.0.57 \times 10^{12} \mathrm{~mol} \mathrm{C} \mathrm{yr}^{-1}\right)$. Recently, we found that the TOC balance through the Strait was $0.45 \times 10^{12} \mathrm{~mol} \mathrm{C} \mathrm{yr}^{-1}$ in June 1997 and $0.38 \times 10^{12} \mathrm{~mol} \mathrm{C} \mathrm{yr}^{-1}$ in April 1998, on average (Dafner et al., 1999). This estimate is similar to the

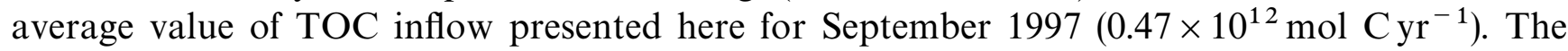
$C_{\mathrm{T}}$ balance from the Mediterranean Sea to the Atlantic Ocean varies from $(12.5 \pm 0.4) 10^{4}$ to

Table 3

Water transport (Sv), salinity, TOC $(\mu \mathrm{M} \mathrm{C})$ and $C_{\mathrm{T}}\left(\mu \mathrm{mol} \mathrm{kg}{ }^{-1}\right)$ values applied for carbon balance estimations (Fig. 5) through the Strait of Gibraltar. According to Bray et al. (1995) and Tsimplis and Bryden (1999), errors in the inflow and outflow transports are considered to be $0.06 \mathrm{~Sv}$

\begin{tabular}{lccc}
\hline Variables & Spartel sill & Tarifa Narrows & Gates of Hercules \\
\hline Atlantic inflow & & & 0.82 \\
Transport & 0.74 & 0.69 & $36.67 \pm 0.17$ \\
Salinity & $36.30 \pm 0.06$ & $36.42 \pm 0.02$ & $89 \pm 7$ \\
TOC & $95 \pm 9$ & $80 \pm 8$ & $2129 \pm 15$ \\
$C_{\mathrm{T}}$ & $2116 \pm 12$ & $2128 \pm 12$ & 0.82 \\
Mediterranean outflow & & & $38.36 \pm 0.02$ \\
Transport & 0.74 & 0.69 & $67 \pm 3$ \\
Salinity & $37.65 \pm 0.50$ & $38.28 \pm 0.02$ & $2310 \pm 2$ \\
TOC & $71 \pm 1$ & $66 \pm 3$ & $2301 \pm 8$ \\
$C_{\mathrm{T}}$ & $2277 \pm 10$ & & \\
\hline
\end{tabular}




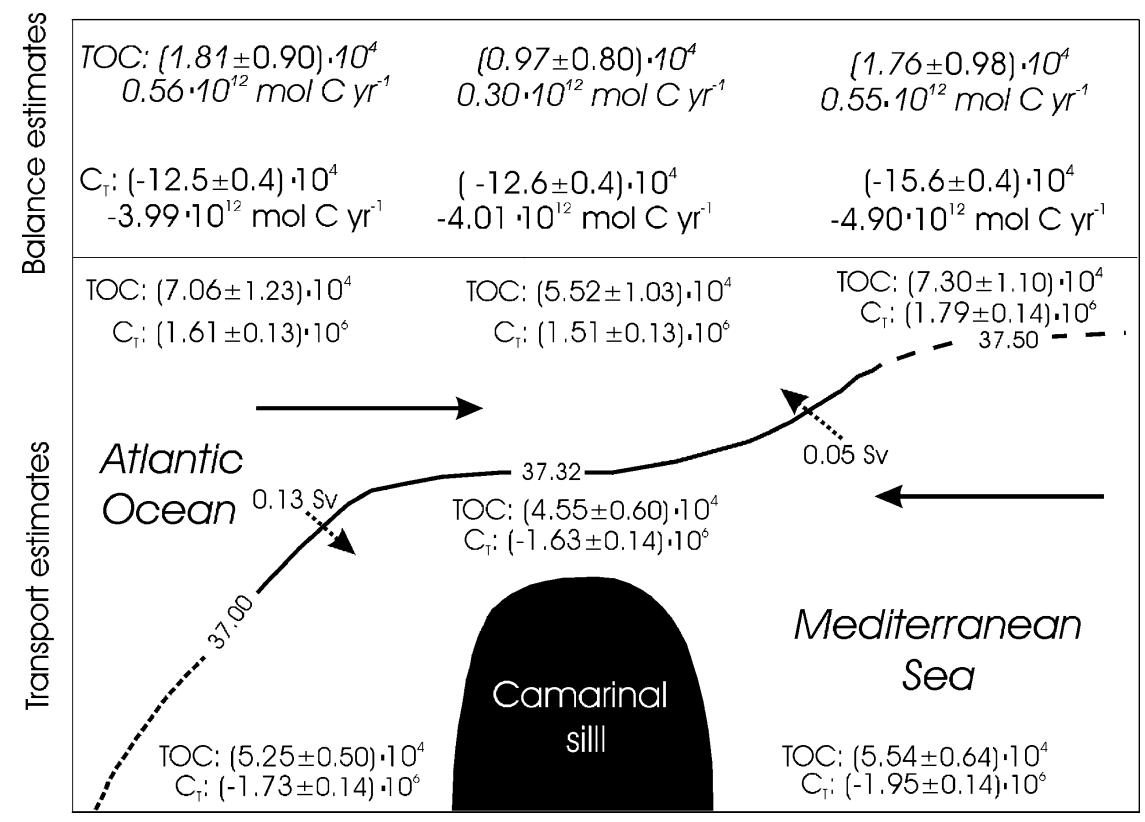

Fig. 5. Two-layer model of water mass exchange through the Strait of Gibraltar with values of TOC and $C_{\mathrm{T}}$ transports (lower panel) and balances (upper panel) along the Strait (2-9 September 1997).

$(15.6 \pm 0.4) 10^{4} \mathrm{~mol} \mathrm{C} \mathrm{s}^{-1}$ for the different longitudinal sections, which gives annual estimates of $3.8 \times 10^{12}-4.9 \times 10^{12} \mathrm{~mol} \mathrm{C} \mathrm{yr}^{-1}$.

The interaction between inflow and outflow results in strong shear, which induces vertical exchange between layers (Wesson and Gregg, 1994; Bray et al., 1995). In order to balance the salinity exchange in the Strait, and considering the input of water and the evaporation are negligible on this area, we estimate that the outflow increases volume transport by the entrainment at $0.13 \mathrm{~Sv}$ from the western entrance. By contrast, the Atlantic inflow increases its volume only by $0.05 \mathrm{~Sv}$ from the eastern entrance of the Strait by mixing with outflow (Fig. 5). The difference in vertical mixing between inflow and outflow from the west and east of the Strait is $-0.08 \mathrm{~Sv}$, in agreement with recent observation of Tsimpis and Bryden (1999). In terms of carbon, these vertical exchanges correspond to $0.87 \times 10^{6}$ and $-0.48 \times 10^{4} \mathrm{~mol} \mathrm{Cs}^{-1}$ for TOC, and $0.11 \times 10^{6}$ and $-0.3 \times 10^{6} \mathrm{~mol} \mathrm{C} \mathrm{s}^{-1}$ for $C_{\mathrm{T}}$. The vertical mixing on the Atlantic side results in an input of organic carbon compounds from the inflow to the outflow and in the opposite direction for inorganic carbon (Tables 2 and 3).

Indirect estimates of organic and inorganic carbon balances were recently published by CopinMontégut (1993). For DOC, she presented a value of $1.25 \times 10^{12} \mathrm{~mol} \mathrm{C} \mathrm{yr}^{-1}$, which is twice as high as our estimations for each longitudinal section. This difference is due to the TOC concentrations used (in her calculation she used DOC values of $67 \mu \mathrm{M} \mathrm{C}$ for the inflowing and $92 \mu \mathrm{M} \mathrm{C}$ for the outflowing waters), rather than different water transport estimates. By contrast, $C_{\mathrm{T}}$ balances obtained by Copin-Montégut and Brunet et al. (1984) $\left(-4.6 \times 10^{12}\right.$ and $\left.-6.1 \times 10^{12} \mathrm{~mol} \mathrm{C} \mathrm{yr}^{-1}\right)$ are the same as we present here despite their use of different water transport estimates. It was estimated that in the Gulf of Cádiz, entrainment increases the observed amount of carbon outflow, to about $8.6 \times 10^{6} \mathrm{~mol} \mathrm{Cs}^{-1}$ for $C_{\mathrm{T}}$ and $2.1 \times 10^{5} \mathrm{~mol} \mathrm{C} \mathrm{s}^{-1}$ for TOC on leaving the outer Gulf of Cádiz (Dafner et al., 2000a). It gives the net carbon transport with the Mediterranean outflow to the 
Table 4

Historical estimates of meridional $\mathrm{TCO}_{2}$ and DOC fluxes in the North Atlantic Ocean. Negative values correspond to southward transport

\begin{tabular}{lll}
\hline Areas & Carbon transport (mol C s ${ }^{-1}$ ) & References \\
\hline Section at $25^{\circ} \mathrm{N}$ and through the Florida Straits & $-0.68 \times 10^{6}$ & Brewer et al. (1989) \\
Temperate North Atlantic & $-1.60 \times 10^{6}$ & Broecker and Peng (1992) \\
Tropical Atlantic & $-1.05 \times 10^{6} \pm 0.48 \times 10^{6}$ & Keeling and Peng (1995) \\
Section $\sim 58^{\circ} \mathrm{N}$, North Atlantic & $-0.16 \times 10^{6}$ & Stoll et al. (1996a) \\
Section $\sim 58^{\circ} \mathrm{N}$, North Atlantic (DOC) & $0.04 \times 10^{6}-0.16 \times 10^{6}$ & Stoll et al. (1996b) \\
\hline
\end{tabular}

open ocean of about $8.8 \times 10^{6} \mathrm{~mol} \mathrm{Cs}^{-1}$. This carbon bulk is about $61.5 \%$ of the amount of fossil fuel $\mathrm{CO}_{2}$ released into the atmosphere currently (ca. $14.3 \times 10^{6} \mathrm{~mol} \mathrm{~s}^{-1}$ ) (Anderson et al., 1991). The estimates of carbon fluxes through the Strait of Gibraltar are similar to those presented recently for the meridional $\mathrm{TCO}_{2}$ and DOC transports in the northern North Atlantic (Table 4). Polat and Tugrul (1996) obtained a value of $1.79 \times 10^{4}$ ton $\mathrm{C} \mathrm{yr}^{-1}$ (or $0.15 \times 10^{10} \mathrm{~mol} \mathrm{Cyr}^{-1}$ ) for

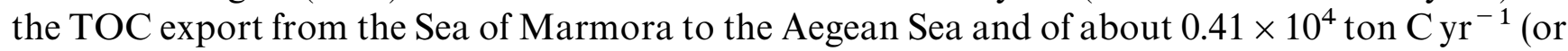
$0.34 \times 10^{9} \mathrm{~mol} \mathrm{C} \mathrm{yr}^{-1}$ ) for the TOC outflow in the opposite direction. As we see, TOC inflow and outflow through the Strait of Gibraltar are two and three orders of magnitude higher than through the Turkish Straits. Several authors have evaluated the budget of dissolved organic nitrogen and phosphorus through the Strait (Béthoux and Copin-Montégut, 1986; Coste et al., 1988). They have found that inflow from the Atlantic Ocean exceeds outflow from the Mediterranean Sea. Our data, together with the results quoted above, indicate that inflow of organic material to the Mediterranean Sea through the Strait of Gibraltar is considerably higher than outflow. The Mediterranean Sea acts as a sink of organic carbon and source of inorganic carbon for the Atlantic Ocean.

\section{Acknowledgements}

The authors gratefully acknowledge F. Abrahansen and M. Goutx for their help with cruise preparation. We thank the crew of the RV Thalassa for their help and support, and L.M. Laglera for his help with sample collection and alkalinity determination. Our special thanks go to J. Sharp, who kindly provided the deep Pacific and carbon-free water reference standards. We thank C. Goyet for critical reading and constructive comments on the developing manuscript. This research was funded by the European Commission, MAST III Programme (Contract MAS3-CT96-0060). Financial support for E.V. Dafner came from Ministere Affaires Etrangères Francais and Conseil Général des Bouches du Rhône, France.

\section{References}

Alpers, W., Brandt, P., Rubino, A., Backhaus, J.O., 1996. Recent contributions of remote sensing to the study of internal waves in the Strait of Gibraltar and Messina. Bulletin de l'Institut océanographique, Monaco 17, 21-40. 
Anderson, L.G., Holby, O., Lindergren, R., Ohlson, M., 1991. The transport of carbon dioxide into the Weddel Sea. Journal of Geophysical Research 96, 16679-16687.

Avril, B., Copin-Montegut, G., 1992. La matiére organique dissoute lors d' "Almofront-1". Workshop Report, Fronts geostrophiques, Marseille-Luminy, octobre, pp. 14-22.

Bellerby, R.G.J., Turner, D.R., Millward, G.E., Worsfold, P.J., 1995. Shipboard flow injection determination of sea water pH with spectrophotometric detection. Analitica Chimica Acta 309, 259-270.

Béthoux, P., Copin-Montégut, G., 1986. Biological fixation of atmospheric nitrogen in the Mediterranean Sea. Limnology and Oceanography 31 (6), 1353-1358.

Boyce, F.M., 1975. Internal waves in the Strait of Gibraltar. Deep-Sea Research 22, 597-610.

Bray, N.A., Ochoa, J., Kinder, T.N., 1995. The role of the interface in exchange through the Strait of Gibraltar. Journal of Geophysical Research 100 (C6), 10755-10776.

Brewer, P.G., Goyet, C., Dyrssen, D., 1989. Carbon dioxide transport by ocean currents at $25^{\circ} \mathrm{N}$ latitude in the Atlantic Ocean. Science 246, 477-479.

Broecker, W.S., Peng, T.-H., 1992. Interhemispheric transport of carbon dioxide by ocean circulation. Nature (London) 356, 587-589.

Brunet, C., Poisson, A., Lebel, J., Porot, V., 1984. Alkalinité totale-carbone inorganique-calcium-densité. In: Propriétiétés Hydrologiques et Climatiques des Eaux du Basin Occidental de la Mediterranée. Compagne Mediprod IV-15 Octobre-17 Novembre 1981, Résultats des Compagnes a la Mer, Vol. 26. Centre National pour l'Explotation des Océans, Brést, France, pp. 89-93.

Bryden, H.L., Stommel, H.M., 1982. Origins of the Mediterranean outflow. Journal of Marine Research 40, $55-71$.

Bryden, H.L., Kinder, T.N., 1988. Gibraltar experiment: a plan for dynamic and kinematic investigations of strait mixing, exchange and turbulence. Oceanologica Acta SP, 29-40.

Bryden, H.L., Brady, E.C., Pillsbury, R.D., 1989. Flow through the Strait of Gibraltar. In: Almazan, J.L., Bryden, H.L., Kinder, T.N., Parilla, G. (Eds.), Seminario Sobre la Oceanografia Fisica del Estrechode Gibraltar. SECEG, Madrid, pp. 166-194.

Bryden, H.L., Kinder, T.N., 1991. Steady two-layer exchange through the Strait of Gibraltar. Deep-Sea Research 38 (Suppl. 1), S445-S463.

Bryden, H.L., Candela, J., Kinder, T.N., 1994. Exchange through the Strait of Gibraltar. Progress in Oceanography 33, 201-248.

Carlson, C.A., Ducklow, H.W., Michaels, A.F., 1994. Annual flux of dissolved organic carbon from the euphotic zone in the northwestern Sargasso Sea. Nature 371, 405-408.

Cauwet, G.A., 1991. Distribution of organic carbon in the Gulf of Lions: the influence of Rhône inputs. In: Martin, J.M., Barth, H. (Eds.), Commission of the European Communities, Water Pollution Research Reports, EROS 2000, Second Workshop on the Northwest Mediterranean Sea, pp. 209-229.

Cauwet, G., 1994. HTCO method for dissolved organic carbon analysis in seawater: influence of catalyst on blank estimation. Marine Chemistry 47, 55-64.

Cauwet, G., Sempéré, R., Saliot, A., 1990. Le carbone organique dissous dans de mer: confirmation de la sous-estimation antérieure. Compe Rendus Academie des Sciences 311 (II), 1061-1066.

Cauwet, G., Miller, A., Brasse, S., Fengler, G., Mantoura, R.F.C., Spitzy, A., 1997. Dissolved and particulate organic carbon in the western Mediterranean Sea. Deep-Sea Research II 44 (3-4), 769-779.

Clayton, T.D., Byrne, R.H., 1993. Spectrophotometric seawater pH measurements: total hydrogen ion concentration scale calibration of $m$-cresol purple and at-sea results. Deep-Sea Research I 42, 411-429.

Conway, T.J., Tans, P.P., Watermark, L.S., Thoning, K.W., Kitzis, D.R., Masarie, K.A., Zhang, N., 1994. Evidence for interannual variability of the carbon cycle from NOAA/CMDL Global air sampling network. Journal of Geophysical Research 99 (D11), 22831-22855.

Copin-Montégun, C., 1993. Alkalinity and carbon budgets in the Mediterranean Sea. Global Biogeochemical Cycles 7 (4), 915-925.

Copin-Montégut, G., Avril, B., 1993a. Vertical distribution and temporal variation of dissolved organic carbon in the North-West Mediterranean Sea. Deep-Sea Research I 40 (10), 1963-1972.

Copin-Montégut, G., Avril, B., 1993b. Dissolved organic carbon in the NW Mediterranean Sea. Annales de l'Institut océanoqraphique, Paris 69 (1), 123-124. 
Coste, B., Le Corre, P., Minas, H.J., 1988. Re-evalution of the nutrient exchange in the Strait of Gibraltar. Deep-Sea Research 35 (5), 767-775.

Dafner, E.V., Sempéré, R., Goutx, M., 1999. Seasonal and interannual variations of organic carbon exchange through the Strait of Gibraltar. In: Parrilla, G. (Ed.), Final Scientific Report CANIGO-MAST 3-CT 96-0060, November, Instituto Español de Oceanografía, 334pp.

Dafner, E.V., González-Dávila, M., Santana-Casiano, J.M., 2000a. Importance of the Mediterranean eddies (Meddies) on the carbon cycling in the eastern North Atlantic Ocean. Global Biogeochemical Cycles, submitted for publication.

Dafner, E.V., Sempéré, R., Bryden, H.L., 2000b. Total organic carbon distribution and budget through the Strait of Gibraltar in April 1998. Marine Chemistry, in press.

Dickson, A.G., 1981. An exact definition of total alkalinity and a procedure for the estimation of alkalinity and total inorganic carbon from titration data. Deep-Sea Research 28, 609-623.

Dickson, A.G., Millero, F., 1987. A comparison of the equilibrium constants for the dissociation of carbonic acid in seawater media. Deep-Sea Research 34, 1733-1743.

Dickson, A.G., 1990. Thermodynamics of the dissociation of boric acid in synthetic sea water from to 273.15 to $318 \mathrm{~K}$. Deep-Sea Research 37, 755-766.

DOE, 1994. In: Dickson, A.G., Goyet, C. (Eds.), Handbook of Methods for the Analysis of the various Parameters of the Carbon-dioxide System in Sea water; Version 2. ORNL/CDIAC-74.

Doval, M.D., Álvarez-Salgado, X.A., Pérez, F.F., 1997. Dissolved organic matter in a temperate embayment affected by coastal local upwelling. Marine Ecology Progress Series 157, 21-37.

Doval, M.D., Pérez, F.F., Berdalet, E., 1999. Dissolved and particulate organic carbon in the northwestern Mediterranean Sea. Deep-Sea Research I 46 (3), 511-527.

Frankingnoulle, M., De Caluwe, M., Bouquegneau, J.-M., 1990. Utilisation de l'alcalinité totale comme traccur de masses d'eau. Bulletin de la Societe Royale des Sciences de Liege 2, 105-111.

Gammon, R.H., Sundquist, E.T., Frazer, P.J., 1985. History of carbon dioxide in the atmosphere. In: Trabalka, J., Rheichle, D. (Eds.), Atmospheric Carbon dioxide and the Global Carbon Cycle: A Global Analysis. Springer, New York, USA.

Gasol, J.M., Doval, M.D., Pinhassi, J., Calderón-Paz, J.I., Guixa-Boixareu, N., Varque, D., Pedrós-Alió, C., 1998. Diel variations in bacterial heterotrophic activity and growth in the north-western Mediterranean Sea. Marine Ecology Progress Series 164, 107-124.

Gründlich, M.L., 1981. On the observation of a solitary event in the Mediterranean outflow west of Gibraltar. "Meteor" Forschungsergebnisse, Reihe A/B 23, 15-46.

Guimerans, V., Cañavate, R., Palma, R., 1988. Contribution to the knowledge of the Gibraltar Sill. In: Almazan, J.L., Bryden, H.L., Kinder, T.N., Parilla, G. (Eds.), Seminario Sobre la Oceanografia Fisica del Estrechode Gibraltar. SECEG, Madrid, pp. 83.

Johnson, K.M., Wills, K.D., Butler, D.B., Johnson, W.K., Wong, C.S., 1993. Coulometric total carbon dioxide analysis for marine studies: maximazing the performance of an automated gas extraction system and coullometric detector. Marine Chemistry 44, 167-187.

Keeling, R.F., Peng, T.-H., 1995. Transport of heat, $\mathrm{CO}_{2}$, and $\mathrm{O}_{2}$ by the Atlantic's thermohaline circulation. Philosophical Transactions of the Royal Society of London, Series B 348, 133-142.

Kinder, T.H., Bryden, H.L., 1990. Aspiration of deep waters through straits. In: Pratt, L.J. (Ed.), The Physical Oceanography of Sea Straits. Kluwer Academic Publishers, Netherlands, pp. 295-319.

Kinder, T.H., Bryden, H.L., 1992. Hydraulic control in the Strait of Gibraltar. Bulletin de l'Institut océanographique, Monaco 11, 113-126.

Lacombe, H., Richez, C., 1982. The regime of the Strait of Gibraltar. In: Nihoul, C.J. (Ed.), Hydrodynamics of Semienclosed Seas. Elsevier, New York, pp. 13-73.

La Violette, P. E., Lacombe, H., 1988. Tidal-induced pulses in the flow through the Strait of Gibraltar. Oceanologica Acta SP, 13-27.

Lee, K., Millero, F.J., Wanninkhof, R., 1997. The carbon dioxide system in the Atlantic Ocean. Journal of Geophysical Research 102, 15693-15707.

Martel, F., Wunsch, C., 1993. The North Atlantic circulation in the early 1980s - an estimate from inversion of a fine difference model. Journal of Physical Oceanography 23, 898-924. 
McElligott, S., Byrne, R.H., Lee, K., Wanninkhof, R., Millero, F.J., Felly, R.A., 1998. Discrete water column measurements of $\mathrm{CO}_{2}$ fugacity and $\mathrm{pH}_{\mathrm{T}}$ in seawater: a comparison of direct measurements and thermodynamic calculations. Marine Chemistry 60, 63-73.

Measures, C.I., Edmond, J.M., 1988. Aluminium as a tracer of the deep outflow from the Mediterranean Sea. Journal of Geophysical Research 93 (C1), 591-595.

Medoc Group, 1970. Observation of formation of Deep Water in the Mediterranean Sea. Nature 227, 1037-1040.

Millero, F.J., Zhang, J.-Z., Lee, K., Campbell, D.M., 1993. Titration alkalinity of seawater. Marine Chemistry 44, $143-152$.

Minas, H.J., Coste, B., Le Corre, P., Minas, M., Raimbault, P., 1991. Biological and geochemical signatures associated with the water circulation through the Strait of Gibraltar and in the Western Alboran Sea. Journal of Geophysical Research 96 (C5), 8755-8771.

Mintrop, L.M., Pérez, F.F., González-Dávila, M., Santana-Casiano, J.M., Körtzinger, A., 1999. Alkalinity determination by potentiometry-intercalibration using three different methods. Ciencias Marinas, in press.

Packard, T.T., Minas, H.J., Coste, B., Martinez, R., Bowin, M.C., Gostan, J., Garfield, P., Christensen, J., Dortch, D., Minas, M., Copin-Montégut, G., Copin-Montégut, C., 1988. Formation of the Alboran oxygen minimum zone. Deep-Sea Research 35 (7), 1111-1118.

Pérez, F.F., Estrada, M., Salad, J., 1986. Sistema del carbónico, oxígeno y nutrientes en el Mediterráneo occidental. Investigacion Pesquera 50 (3), 333-351.

Polat, Ç., Tugrul, S., 1996. Chemical exchange between the Mediterranean and the Black Sea via the Turkish straits. Bulletin de l'Institut océanographique, Monaco, CIESM Science Series 2 SP 17, 167-186.

Rios, A.F., Anderson, T.R., Pérez, F.F., 1995. The carbonic system distribution and fluxes in the NE Atlantic during Spring 1991. Progress in Oceanography 35, 295-314.

Roether, W., Weiss, W., 1975. On the formation of the outflow through the Strait of Gibraltar. Geophysical Research Letter 2, 301-304.

Roy, R.N., Roy, L.N., Lawson, M., Vogel, K.M., Porter-Moore, C., Davis, W., Millero, F.J., Campbell, D.M., 1993. Determination of the ionization constants of carbonic acid in seawater. Marine Chemistry 44, 249-259.

Siegenthaler, U., Sarmiento, J.L., 1993. Atmospheric carbon dioxide and the ocean. Nature 365, 119-125.

Stommel, N., 1972. Deep winter-time convection in the western Mediterranean Sea. In: Gordon, A.L. (Ed.), Studies in Physical Oceanography., Vol. 2. Gordon and Breach, New York, pp. 232.

Stanton, B.R., 1983. Low frequency variability in the Mediterranean Outflow west of Gibraltar. Deep-Sea Research 30 (7A), 743-761.

Stoll, M.H.C., Van Aken, H.M., De Baar, H.J.W., De Boer, C.J., 1996a. Meridional carbon dioxide transport in the northern North Atlantic. Marine Chemistry 55, 205-216.

Stoll, M.H.C., Van Aken, H.M., De Baar, H.J.W., Kraak, M., 1996b. Carbon dioxide characteristics of water masses in the northern North Atlantic. Marine Chemistry 55, 217-232.

Tans, P.P., Fung, I., Takahashi, T., 1990. Observational constrains on the global atmospheric $\mathrm{CO}_{2}$ budget. Science 247, 1431-1438.

Thomas, C., Cauwet, G., Minster, J.-F., 1995. Dissolved organic carbon in the equatorial Atlantic Ocean. Marine Chemistry 49, 155-169.

Tsimplis, M., Bryden, H.L., 1999. Estimation of transport through the Strait of Gibraltar. Geophysical Research Abstracts, Vol. 1(2). 24th General Assembly, European Geophysical Society, The Hague, p. 392.

Van Geen, A., Rosener, P., Boyle, E., 1988. Entrainment of trace-metal-enriched Atlantic-shelf water in the inflow to the Mediterranean Sea. Nature 331, 423-426.

Van Geen, A., Boyle, E., Moore, W.S., 1991. Trace metals enrichments in waters of Gulf of Cadiz, Spain. Geochimica et Cosmochimica Acta 55, 2173-2191.

Walsh, J.J., Carder, .K.L., Müller-Karger, F.E., 1992. Meridional fluxes of dissolved organic matter in the North Atlantic Ocean. Journal of Geophysical Research 97 (C10), 15625-15637.

Watson, A.J., Nightingale, P.D., Cooper, D.J., 1995. Modelling atmosphere-ocean $\mathrm{CO}_{2}$ transfer. Philosphical Transactions of the Royal Society of London B 348, 125-132. 
Wesson, J.C., Gregg, M.C., 1994. Mixing at Camarinal Sill in the Strait of Gibraltar. Journal of Geophysical Research 99 (C5), 9847-9878.

Yoro, S.C., Sempéré, R., Turley, C., Unanue, M.A., Durrieu De Madron, X., Bianchi, M., 1997. Cross-slope variations of organic carbon and bacteria in the Gulf of Lions in relation to water dynamics (northwestern Mediterranean). Marine Ecology Progress Series 161, 255-264. 